KUML 1997-98 


\section{KUML 1997-98 Årbog for Jysk Arkæologisk Selskab}

With summaries in English 
Redaktion: Hans Jorgen Madsen og Jesper Laursen

\section{Omslag: Louise Hilmar}

Tilrettelagning: Narayana Press

Tryk: Narayana Press

Skrift: Bembo 12/13

Papir: $115 \mathrm{~g}$ Arctic Silk

Copyright (C) 1998 by Jysk Arkaologisk Selskab

ISBN 87-7288-597-1

ISSN 0454-6245 


\section{Indhold/Contents}

Hans Jorgen Madsen og Else Roesdahl: Olaf Olsen 70 år $\ldots \ldots \ldots \ldots \ldots \ldots \ldots \ldots$

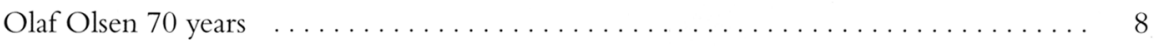

Søren H.Andersen: En mønstret pragtøkse fra ældre Ertebølletid $\ldots \ldots \ldots \ldots \ldots \ldots$.

A Magnificent ornamented axe from the Early

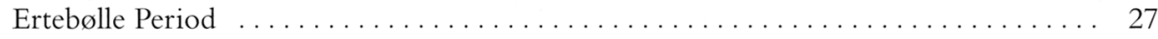

Henrik Skousen: Rønbjerg Strandvolde - en kystboplads

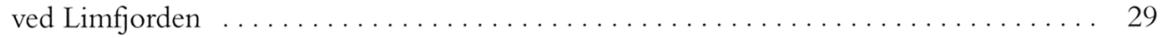

Rønbjerg Strandvolde - a coastal settlement by the Limfjord $\ldots \ldots \ldots \ldots \ldots \ldots \ldots 71$

Lisbeth Christensen: Vandet skole - en ældre romertidsgrav med

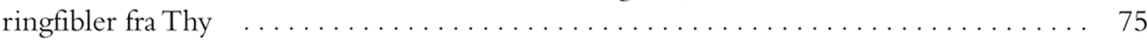

An Early Roman Iron Age grave with ring brooches from

Vandet School in Thy ........................................ 103

Bjarne Henning Nielsen: Jernalderfund fra Egådalen . . . . . . . . . . . . . . . . . 105

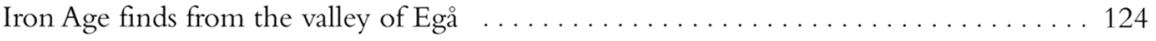

Elisabeth Barfod Carlsen: Et smykke i slægt med guldbrakteaterne $\ldots \ldots \ldots \ldots \ldots \ldots . \ldots 127$

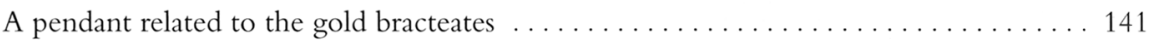

Claus Feveile, Stig Jensen og Kaare Lund Rasmussen: Produktion

af drejet keramik i Ribeområdet i sen yngre germansk jernalder $\ldots \ldots \ldots \ldots \ldots \ldots 143$

The production of thrown pottery in the Ribe area towards

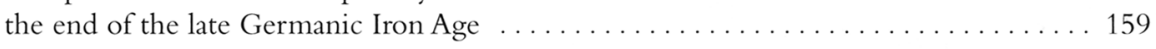

Ole Crumlin-Pedersen: Skibsfundene fra Hedeby $\ldots \ldots \ldots \ldots \ldots \ldots \ldots \ldots$

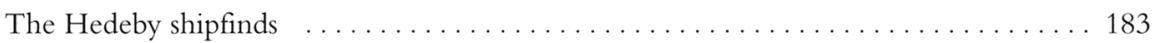

Anne Pedersen: Bidselbeslag fra Bøgeskov Strand . . . . . . . . . . . . . . . . . . . 185

A Harness Cheek-piece from Bøgeskov Strand ....................... 194

Bente Holmberg og Jan Skamby Madsen: Da kom en snekke ... . . . . . . . . . . . . . 197

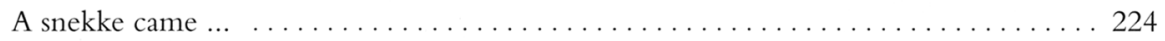

Hans Skov: Udgravningerne i Århus Midtby 1994-97 . . . . . . . . . . . . . . . . 227

The excavations in the centre of Aarhus 1994-97 . . . . . . . . . . . . . . . . . 292

Thomas Bertelsen: Kirketage ........................................ 295

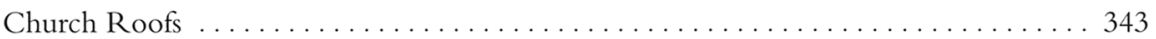

Anmeldelser .................................................. 347

Jysk Arkæologisk Selskab 1997 . . . . . . . . . . . . . . . . . . . . . . . . 369

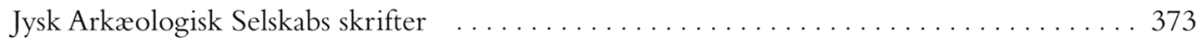




\title{
Jernalderfund fra Egådalen
}

\author{
Af Bjarne Henning Nielsen
}

I de første tre årtier af dette århundrede tilbragte Nationalmuseets Carl Neergaard lang tid med udgravning af grave fra den ældre jernalder ved Lisbjerg lige nord for Århus. Aldrig så snart var han færdig med en gravplads, før en ny dukkede op, og i løbet af årene fik han udgravet adskillige gravpladser helt eller delvist. Den største og kendteste er Bulbjerggravpladsen øst for Lisbjerg Skov med mere end 100 grave. $^{1}$

På en del gravpladser blev fundet brandgrave af flere typer fra den del af jernalderen, der bliver benævnt førromersk jernalder. Men langt de fleste stammede fra tiden ca. 0-200 e.Kr. - også kaldet ældre romersk jernalder. Disse gravlæggelser var jordfæstegrave af en type, der blev omtalt som østjyske lerkargrave. Det blev de, fordi den døde meget ofte fik mad- og drikkevarer med i graven, og forsyningerne var anrettet i lerkar, der blev placeret foran den døde. Nogle gravlagte fik rigeligt med; mere end ti lerkar er det ikke usædvanligt at finde i en grav. Store og små kar, krukker, skåle, fade og drikkebægre.

Gravanlæggene er for det meste bredt rektangulære, og de kan have stenramme som støtte for en plankekiste. Stenrammen kan være meget kunstfærdigt udført og bestå af mange sten eller måske blot af enkelte sten til støtte for gravens plankesider. Gravene kan også være uden sten, og kisteplankerne blev så holdt på plads af endestykkerne eller bare af jord. Kisterne havde låg af træ og over graven kunne blive lagt et tæppe af mest mindre sten. Disse sten sank siden ned $\mathrm{i}$ graven, når kisten på et tidspunkt rådnede. Gravene kunne også have brolægning af sten i bunden. Elementerne blev kombineret på forskellig vis.

Der var regler for begravelserne, som næsten altid blev overholdt. Både mænd og kvinder blev lagt på højre side med optrukne ben og armene bøjet op foran hovedet og ansigtet vendt mod syd. Det er meget sjældent, at der er bevaret skeletrester i gravene, men af og til har det været muligt at skelne en aftegning af den døde i form af stærkt opløste eller pulveriserede knogler. Til tider også af såkaldt ligfedt, som gør det muligt at skelne kroppens konturer, nærmest som en skygge. Den døde var klædt i sit bedste eller måske eneste tøj. Kvinderne var ofte gravlagt med deres smykker. Smykkerne sad på dragten, på kroppen, om halsen eller $i$ håret. Mændene havde kun sjældent pynt. Af og til kunne en kappe dog være lukket ved halsen af en enkelt fibel, for det meste af jern. Mændene kun- 
ne også en sjælden gang bære en guldfingerring. Begge køn havde i reglen en eller måske to jernknive liggende ved lerkarrene. For det meste var det kun mænd, der havde bælte, men nu og da kunne en kvinde også have det.

Carl Neergaard fik aldrig udarbejdet et endeligt værk om sine fund, men de grundlæggende træk og beskrivelser fik han dog fremlagt i mindre artikler. I 1956 udgav museumsinspektør Hans Norling-Christensen et stort katalog over Neergaards og andres undersøgelser af grave fra den ældre romerske jernalder. ${ }^{2}$ Værket omfattede gravfundene fra hele det gamle Århus Amt og viste, hvordan gravformen i princippet var den samme overalt. Keramikken fra Bulbjerggravpladsen er siden blevet analyseret af arkæologen Mette Høj med hensyn lerkartypernes udvikling og hvilke kombinationer, de indgik i. ${ }^{3}$

C. Neergaard fandt til tider også spor af de bopladser, som benyttede gravpladserne. Det blev dog aldrig til nogen tilbundsgående undersøgelse, set med nutidens øjne, men han fandt til gengæld bevarede lergulve fra jernalderhusene. Sådanne lergulve skal man ikke gøre sig mange forhåbninger om at finde nu om dage, hvor det moderne landbrug med effektive maskiner for længst har pløjet sig dybt ned gennem sådanne lag.

De arkæologer, som foretog de forste store boplads- eller landsbyudgravninger, lagde deres arbejde i Vestjylland og Thy, ikke i Østjylland. Fra slutningen af 1960'erne tog udviklingen fart, dog stadig i Vestjylland. $\mathrm{Nu}$ begyndte arkæologerne selv at benytte maskinkraft til at fjerne pløjejorden med. I undergrunden viste sig nemlig stolpehullerne efter de jordgravede stolper i husene. Med maskine kunne man nu hurtigt og relativt billigt afrømme store arealer og således få opmåt hele den pågældende bebyggelse. I de sidste 25-30 år er landsbyer og et stort antal hustomter landet over blevet udgravet, og vi har efterhånden et godt billede af, hvordan hustyperne udvikler sig igennem oldtiden.

Med hensyn til selve landsbyens udformning i den senere del af ældre jernalder, den tid vi vil beskæftige os med her, må man efterhånden sige, at det kan være vanskeligt at definere klare regler for, hvordan den har set ud. Meget tyder dog på, at det er helt lokale forhold, der bestemmer den enkelte landsbys udseende og udvikling.

Forhistorisk Museum Moesgård har siden 1970'erne deltaget i jagten på landsbyerne fra jernalderen. Men det er først fra begyndelsen af 1990'erne, at lokaliseringen og udgravning af bopladserne tog fart. ${ }^{4}$ Der var flere grunde til denne voldsomme arkæologiske aktivitet. Langs Egådalen var det først og fremmest Århus og Hinnerup Kommuners ønsker om at fă gjort især store erhvervsarealer klar til salg. ${ }^{5}$

Der blev ved disse udgravningskampagner undersøgt levn fra de fleste forhistoriske perioder, men her skal det dreje sig om gravpladser og 
Fig. 1. 1:100000 kort med angivelse af 1. Lisbjerg Terp bopladsen, 2. Børglumvej, 3. Sommerlyst I, 4. Sommerlyst II, 5. Skejby Sygehus landsbyen. Bopladser er markeret med sort firkant, gravpladser med sort prik. Tegning: Ib Radoor.

1:100,000 map with the settlements indicated: 1. The Lisbjerg Terp settlement, 2. Børglumvej, 3. Sommerlyst I, 4. Sommerlyst II, 5. The Skejby Hospital village. Settlements are marked by a square, burial grounds by a dot. Drawing by Ib Radoor.

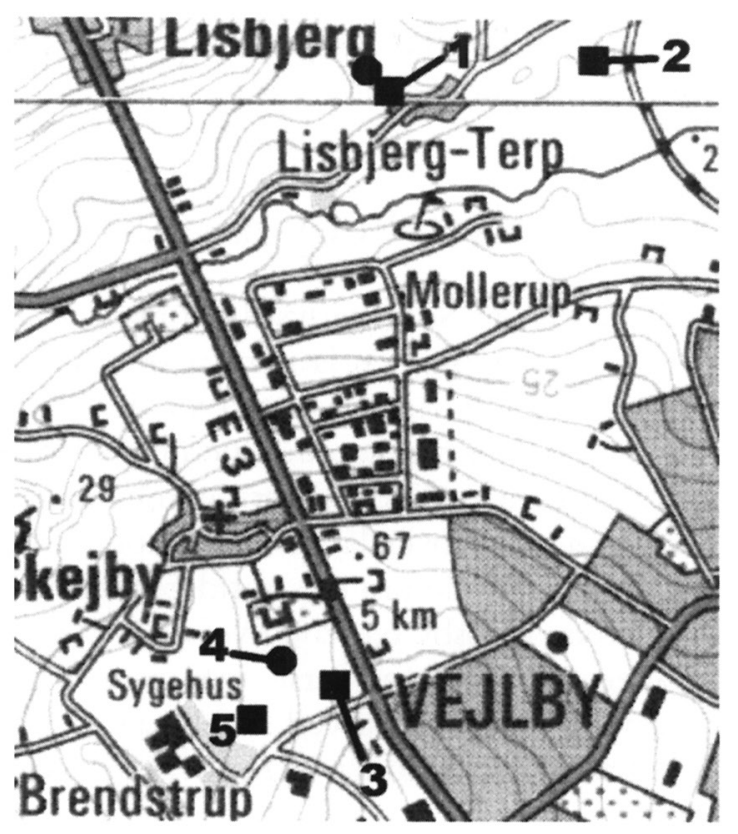

bopladser fra sen førromersk og ældre romersk jernalder. I årstal svarer det til tiden ca. 50 f.Kr. til ca. 200 e.Kr. Det er imidlertid formålet med denne artikel dels at præsentere de nye fund, dels at forsøge at inddrage det ældre fundmateriale. Dette vil forhåbentlig kunne sætte det store, gamle gravfundsmateriale ind $i$ en ny sammenhæng og dermed bidrage til en bedre forståelse af fundene.

Egådalen er en bred tunneldal i det karakteristiske østjyske, storbakkede landskab. Dens sider kan være ret stejle, men kan også falde jævnt mod dalens bund både mod nord og syd. I den vestlige ende af dalen ligger det øvre løb af Lilleåen, der fortsætter i sin egen dalsænkning mod nord. Egåen selv har sit udspring i Geding Sø, og ved dens øvre løb ligger store moseområder. Herfra løber åen mod øst igennem engområder og munder lidt øst for Lisbjerg ud i den gamle og forlængst tilgroede fjord, som nu udgør Lystrup Enge. Hvorvidt der endnu i jernalderen har stået åbent vand i dele af fjordområdet er usikkert. Tidligere var Egåen langt mere vandførende end i dag, men vandindvinding har medført en kraftig reduktion i vandmængden.

Jorden på skråningerne i og områderne oven for dalen hører til blandt de bedste i Jylland. Men den består af fed ler og har været vanskelig at bearbejde. Det synes dog ikke at have afholdt jernalderbønderne fra at gøre det. Nogle steder er der store mængder sten, der til enhver tid har besværliggjort markarbejdet, men heller ikke det kunne stoppe landbruget. 
Egådalen frembød eng, ferskvand og ager til dyr og afgrøder. Det var forudsætninger, der nok kunne tiltrække jernalderfolk.

\section{Sommerlyst-bebyggelsen}

Syd for gården Sommerlyst lå bopladsen Sommerlyst I, og omkring 100 $\mathrm{m}$ nord for bopladsen lå den måske tilhørende gravplads Sommerlyst II (fig. 1 og 2). ${ }^{6}$ På samme mark blev der ved prøvegravninger helt nede ved Skejby Sygehus fundet endnu en bebyggelse af landsbytype, der gav keramikmateriale med en datering meget lig Sommerlyst I-landsbyen. De udgravede landsbyer lå altså kun nogle få hundrede meter fra hinanden. Der kan være tale om to samtidige landsbyer, men der er snarere tale om, at den ene landsby blev opgivet og flyttet hen til det andet sted. Svaret på hvilken, der så kom først, må vi afvente, indtil der kan foretages en udgravning af pladsen ved sygehuset.

Andre steder i landet og for den sags skyld også her i området, kan man

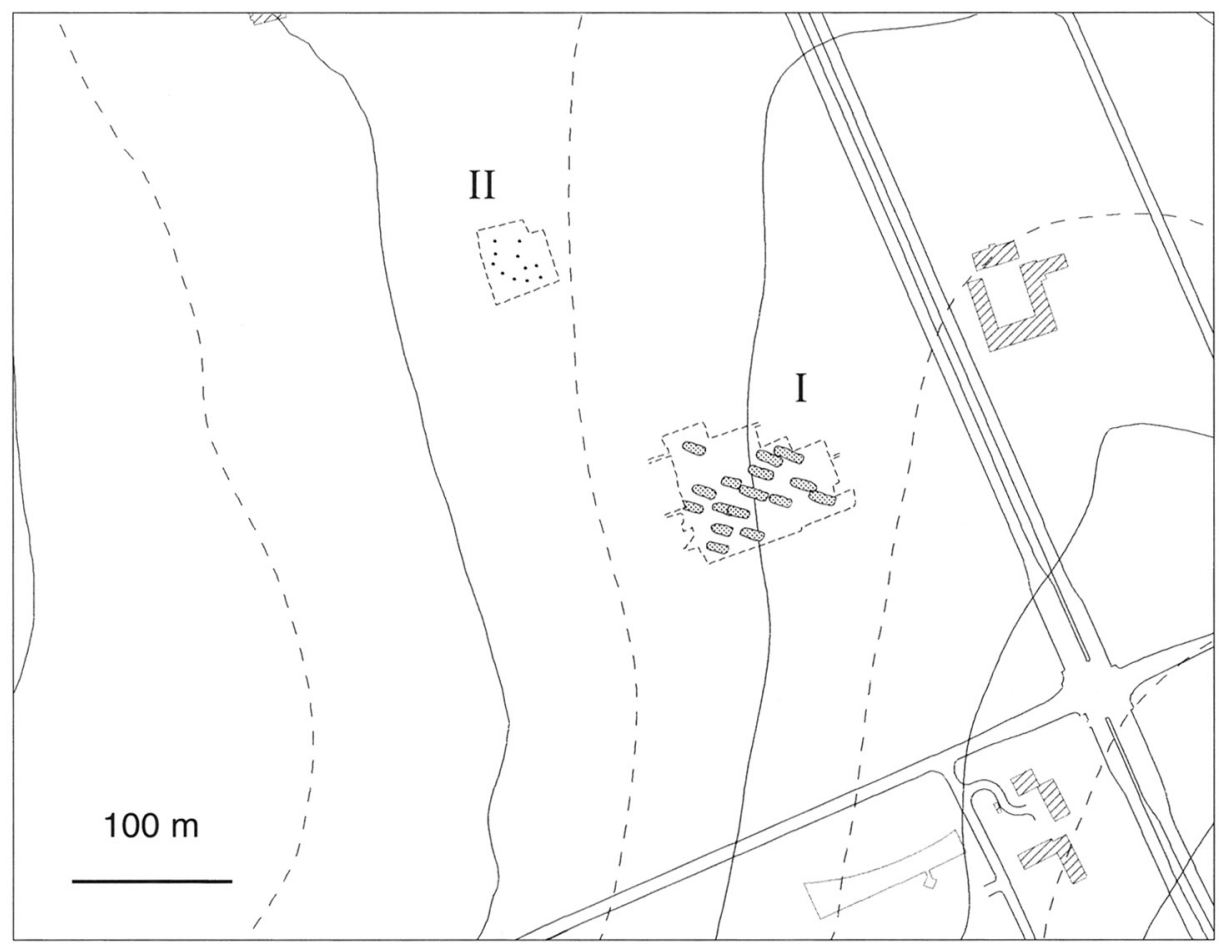

Fig. 2. Ca. 1:1000 oversigtsplan af Sommerlyst I og II. Kortet viser gravpladsens placering i forhold til landsbyen. Tegning: Ib Radoor.

C. 1:1,000 plan of the Sommerlyst I and II sites. The plan shows the situation of the burial ground in relation to the village. Drawing by Ib Radoor. 


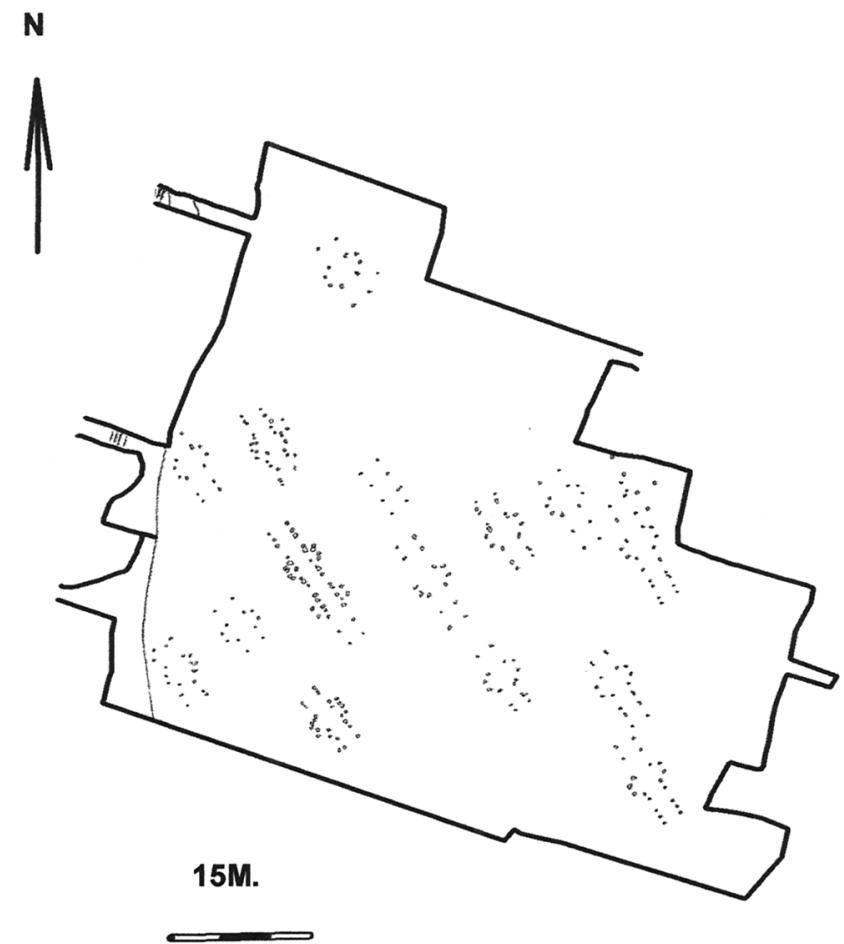

Fig. 3. Oversigtsplan af Sommerlyst I landsbyen med angivelse af de enkelte huse/gårde. Alle øvrige gruber, stolpehuller, grøfter osv. er ikke tegnet med. Tegning: BHN og Ib Radoor.

Survey of the Sommerlyst I village with the individual houses/farms indicated. All other pits, post holes, ditches etc. have been excluded. Drawing by BHN and Ib Radoor.

se lignende flytninger af landsbyer i ældre jernalder. Faktisk mener mange arkæologer, at sådanne landsbyflytninger var almindelige i ældre jernalder. Adskillige steder kan man iagttage, at en landsby blev flyttet efter at have ligget samme sted i ca. 150 år. I tidsrummet fra 50 f.Kr. til 200 e.Kr. kunne der altså i teorien forekomme mindst en flytning.

Vi ved ikke med fuldstændig sikkerhed, om den undersøgte gravplads hørte til Sommerlyst I eller landsbyen ved sygehuset. Men man kan forestille sig, at brugen af gravpladsen fortsatte, selvom man flyttede landsbyen.

Sommerlyst I bestod af 16 langhuse, alle orienteret VNV-ØSØ (fig. 3). Gårdene eller langhusene lå tilsyneladende spredt jævnt ud over udgravningsfeltet. Der var ikke nogen småhuse, som ellers er almindelige på bopladser fra denne tid. Husene var bevaret ved deres tagstolpehuller og indgangsstolpehuller. Tagstolpehullerne i langhusene viste, at der havde været foretaget fuldstændige ombygninger af nogle huse, mens der $i$ andre kun var udført reparationer. I fem langhuse var det muligt at udskille tre hovedfaser. Otte langhuse havde to hovedfaser, mens der i fire blot kun- 
ne erkendes en hovedfase. Husene havde fire til seks sæt tagstolper. En del langhuse kunne fra fase til fase vise udvidelse af længden med et yderligere sæt tagstolper, fra fire til fem sæt eller fra fem til seks sæt. I enkelte tilfælde blev set afkortninger af huse, f.eks. fra seks til fem sæt. En forøgelse med et sæt svarer til en forlængelse med ca. 3 meter. Placeringen af indgangsstolperne angiver samtidig, at bredden af husene var omkring fem meter. Når et hus blev forlænget med et ekstra sæt tagstolper, voksede husets areal med $15 \mathrm{~m}^{2}$. Længden af husene lå mellem 10-18 meter.

Langhusene i ældre jernalder bestod af en beboelsesende i vest og en staldende i øst. Indgangene i husenes langsider ledte formentlig ind til et mindre rum, som adskilte beboelsen og stalden. Der har derfor sandsynligvis være skillerumsvæg ved det første sæt tagstolper vest for indgangene, samt ved det første sæt tagstolper øst for indgangene. Beboelsesdelen kunne have to eller tre sæt tagstolper, men der kunne i det enkelte langhus udvides fra to til tre sæt tagstolper eller sågar ændres fra tre sæt til to sæt og tilbage til tre sæt tagstolper. Dette sidste blev set i to langhuse.

Langhusene lå for det meste fixeret på det samme sted i alle byggefaser. Der var kun ringe mulighed for at flytte. Pladsens største langhus, Gård I, må være det bedste eksempel på denne fixering. Gård I blev tolket som landsbyens hovedhus. Det udviste tre byggefaser, hver med sine reparationer. De to ældste byggefaser lå næsten lige oven $\mathrm{i}$ hinanden, mens den yngste var forskudt mod øst i husets længderetning.

Et par steder kunne det med sikkerhed slås fast, at to huse ikke havde ligget der samtidig. Det drejede sig om Gård IX og XIII, samt Gård XIV og XV. I begge tilfælde syntes langhuset at blive forskudt imod sydøst. Gård XVI kan næppe heller være samtidig med Gård XV, men nok med Gård XIV. Efter iagttagelserne på stedet må i hvert fald tre langhuse skilles ud som en yngre fase i landsbyen bestående af Gård I, fase 3 samt Gård IX og Gård XV. Det ses på grund af flytningen mod øst eller sydøst. Om der var flere langhuse, der rykkede mod øst, er uvist.

Dette leder naturligvis til betydelig usikkerhed om, hvor mange langhuse, landsbyen egentlig bestod af på et givet tidspunkt. Det må også tages under overvejelse, om en gård bestod af mere end et langhus, men en vurdering af oversigtsplanen lader måske formode, at de lidt mindre huse var knyttet til de større.

Tre andre langhuse må også være samtidige. Efter alt at dømme nedbrændte de på samme tid under en storbrand i landsbyen. Det drejer sig om Gård I, fase 2 samt om Gård 3, fase 3 og Gård XI, fase 2. Gård I og XI blev genopført på samme parcel efter branden, Gård I blev dog, som nævnt, rykket mod øst. Gård III blev enten opgivet eller måske opført som Gård IV. Med denne iagttagelse er antallet af mulige samtidige huse forøget til mindst fem.

De tre nedbrændte huse havde et særegent fælles træk. Hullerne efter 
tagstolperne havde et massivt indhold af, hvad der må betegnes som hvidbrændt lerslagge. Slaggen forekom ikke i indgangshullerne. Slaggetypen blev også fundet i små mængder eller som enkeltstykker i stolpehuller i yngre huse, og den fandtes også i en del gruber, især de store lertagningsgruber, som blandt andet rummede husenes affald.

Analyser af den hvide lerslagge og af rødbrændt lerklining fundet $i$ affaldsgruberne, samt af råleren på landsbygrunden, gav som resultat, at den rødbrændte lerklining og råleren bestod af samme bestanddele. ${ }^{7}$ Lerklining blev derfor sandsynligvis fremstillet af den ler, der blev udvundet i gruberne. Den blev magret med sand og derpå anvendt. Årsagen til rødbrændingen var formentlig, at man efter at have revet et gammelt hus ned og fjernet de genanvendelige materialer, afbrændte resterne af huset på tomten, hvorved lerkliningen blev rødbrændt.

Den hvide lerslagge må derimod være opstået ved en samtidig brand i de tre nævnte huse, men i ekstrem varme og under nærmest iltreducerede forhold. Det iltfattige miljø og meget høje temperaturer kunne opstå inde $i$ et hus, men næppe ved dets indgange, hvor adgangen til ilt var rigelig. Der blev derfor ikke dannet slagge i indgangsstolperne.

Det var ikke alene dannelsen af den hvide lerslagge, der var bemærkelsesværdig. Analyserne viste nemlig, at lerslaggen havde et højere indhold af kalk/kridt end bopladsens rødbrændte lerklining og råleren. Denne forskel må betyde, at den jord eller ler, der blev stampet ned omkring stolperne i de brændte huse, ikke kunne være den samme som den, der blev gravet op for at give plads til stolperne. Der måtte være tale om en fyld, der enten var magret med kalk/kridt, eller en særlig ler, der var ført til pladsen fra en ressource uden for. I begge tilfælde må der være tale om en meget klar holdning til, hvordan fylden omkring en tagstolpe skulle være sammensat. Det var ikke muligt at afgøre, om denne funderingspraksis kun blev brugt i de tre nedbrændte huse, eller om den også blev anvendt $\mathrm{i}$ de andre huse $\mathrm{i}$ landsbyen.

\section{Gravpladsen}

Landsbyens gravplads lå ca. $150 \mathrm{~m}$ nordvest for bopladsen på en svag forhøjning i terrænet (fig. 2). Der var foruden 14 jordfæstegrave også et par urnegrave, en urnebrandgrube, en lerkarnedsættelse og et ildsted. Alt lod sig datere til ældre romersk jernalder. ${ }^{8}$

To grave skilte sig ud. Den ene var en stor mandsgrav (fig. 4). Manden var i princippet begravet som alle andre med en stor lerkaropstilling, men lerkarrene var af en bedre kvalitet end normalt. Derudover havde han en jernkniv og en fibula af jern til at holde hans kappe samlet. Graven var næsten tre meter lang, to meter bred og 0,60 meter dyb. Bunden var fint brolagt, og der var sat en massiv stenramme omkring kisten. Endelig var 


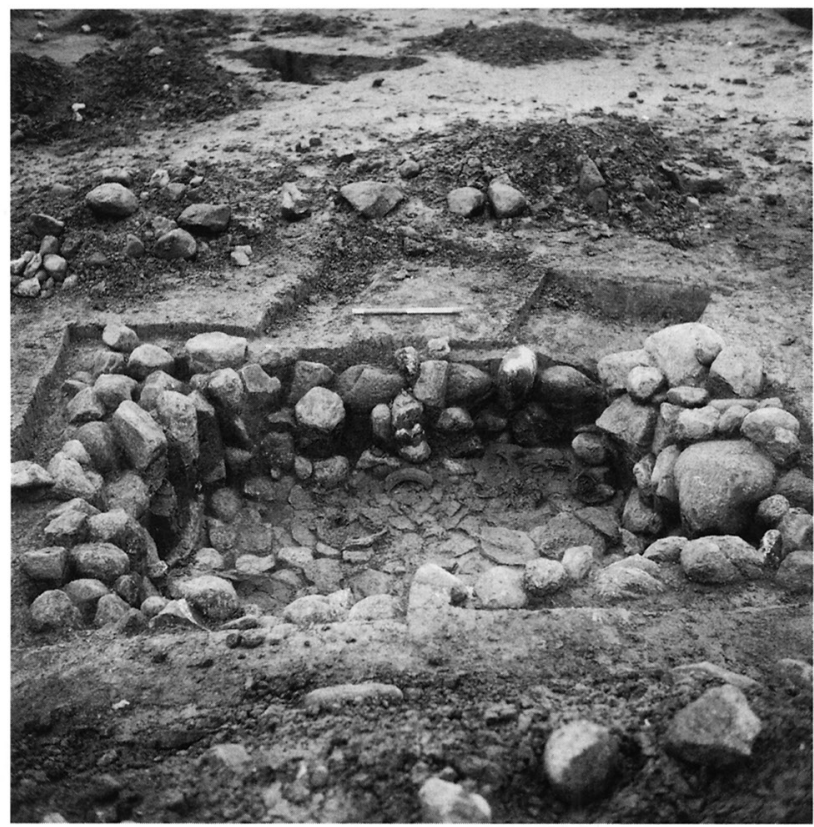

Fig. 4. Den store mandsgrav, Sommerlyst II. Lerkarrene ligger i gravens fjerne side og er helt sammentrykkede. Målestokken ligger på bunden af den færdiggravede yngre grav med strandstensstentæppet. Foto: BHN

The large man's grave. The pottery vessels had been placed at the far end of the grave and had subsequently been damaged by pressure. The measure is lying on the bottom of a secondary, stone covered grave. Photo: BHN.

der lagt et stentæppe over graven. Et omrids af den dødes krop kunne forsigtigt graves frem. Selvom der skulle være plads til mange lerkar, synes gravrummet at være voldsomt overdimensioneret i forhold til den døde mand.

Lige ved siden af mandsgraven lå en kvindegrav, bygget på næsten samme måde, men gravudstyret overgår mandens. At det var en kvindegrav vidner de følgende genstande om. Der var en hårnål af bronze, en sølvfibel og to bronzefibler. En s-formet hægte af sølv havde holdt sammen på snoren $\mathrm{i}$ en halskæde med glasperler. Af disse var flere med indlagt guldfolie. Desuden var der store ravperler, som efter alt at dømme har siddet $\mathrm{i}$ kvindens hår, måske $\mathrm{i}$ en fletning eller hestehale ned langs ryggen. Denne fundsammensætning er yderst sjælden og var forbeholdt socialt meget højt stillede personer. ${ }^{9}$

Ingen af gravpladsens øvrige grave var nær så rigt udstyret som de to beskrevne, men der var dog flere med ben- og bronzenåle, fibler og glasperler og så masser af lerkar. En grav lappede ind over den store mandsgrav. Hvor den dødes brystregion havde været, lå nogle glasperler, hvoraf to havde indlagt guldfolie. Denne grav havde også en bronzefibula og en dårligt bevaret sølvgenstand, ved bæltestedet sås et spænde af jern og en jernkniv. Over graven var lagt et stentæppe, ikke som vanligt af marksten, men af strandsten, som jo må være hentet flere kilometer borte.

I en urnebrandgrube var selve urnen placeret med bunden opad. I gravfylden lå blandt andet en hvidbrændt, ornamenteret bennål. I en jordfæ- 
stegrav var anvendt en gammel dør som dække over graven. Døren havde været delvist brændt og lå bevaret som trækul.

\section{En enkelt gård på Børglumvej}

Børglumvej betegner en lille boplads bestående af blot en enkelt gård (fig. 1). ${ }^{10}$ Gården havde kun et langhus i et par faser samt en tilhørende lille bygning. Den sidste kan have haft adskillige funktioner, mens langhuset bestod af beboelsesende $\mathrm{i}$ vest og stald i øst. Gården lå ret tæet ned til Lystrup Enge, og lige sydvest for gården lå en lille sø, der nu henligger som mose. Blandt andet ved hjælp af de lerkarskår, der blev fundet i mosen, var det muligt at identificere det lag, der blev dannet, mens gården eksisterede. Heri var bevaret planterester, dels af de planter man dyrkede, dels af dem man udnyttede ved indsamling. Dette botaniske materiale er blevet analyseret, og det giver et meget detaljeret billede af planteverdenen i området. Landskabet var åbent og næsten træløst. Man dyrkede forskellige typer byg og hvede og antagelig havre. En del urter kan være indsamlet. Den lille sø blev aldrig forurenet af gårdens affald og dyr. Man har åbenbart benyttet søen som vandforsyning og passet godt på, at den forblev ren. Der kan ikke knyttes nogen grave til bosættelsen.

\section{Lisbjerg- og Bulbjergpladserne}

Ved Lisbjerg Terp er fundet enkelte grave fra ældre romersk jernalder, men endnu ingen huse. Gravene blev fundet, mens Carl Neergaard arbejdede i området. Med forsigtighed må det foreslås, at der kan være tale om en lille gravplads til en enkeltgård af samme type som Børglumvej (fig. 1).

Bevæger vi os fra de lave områder i bunden af dalen op lige nord for det nutidige Lisbjerg, støder vi ind i et væld af gravpladser fra især ældre romersk jernalder. Mange af pladserne blev anlagt i den sene del af førromersk jernalder, og på nogle er der også fundet grave fra begyndelsen af førromersk jernalder. Disse ældre grave vil dog ikke blive inddraget $\mathrm{i}$ dette arbejde. Der er ikke fundet et tilsvarende antal bopladser, for slet ikke at tale om udgravede bopladser. Man har dog kendskab til to sikre lokaliteter. Den ene er opkaldt efter gården Rugård, den anden benævnes Lisbjerg II (fig. 5). Carl Neergaard gravede på Rugårdbopladsen, mens han undersøgte nogle gravpladser på gårdens jorde. Men nogen bestemmelse af pladsen kom han ikke frem til, bortset naturligvis fra, at det var en boplads, og at der var bevarede lergulve.

Der er ikke siden foretaget større arkæologiske undersøgelser på Rugård, men markvandringer på lokaliteten overbeviser dog om, at der 


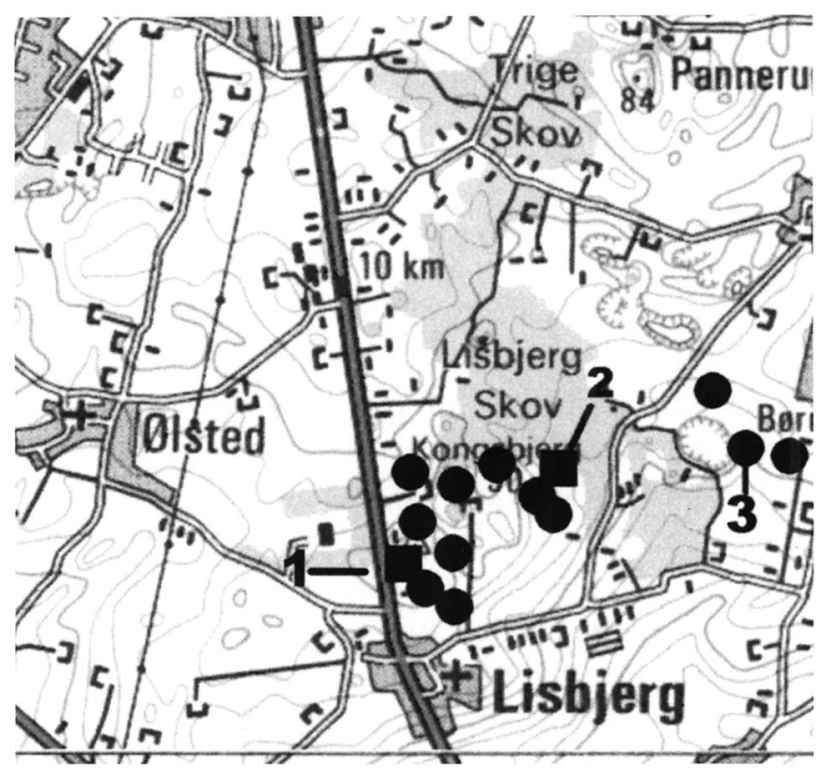

Fig. 5. 1: 100000 kort med angivelse af 1. Rugård bopladsen, 2. Lisbjerg II bopladsen, 3. Bulbjerggravpladsen. Øvrige gravpladser er afsat med sort prik. Tegning: Ib Rudoor.

Fig. 5. 1:100,000 map showing: 1.The Rugård settlement, 2. The Lisbjerg II setlement. 3. The Bulbjerg II settlement. Other settlements are marked with a dot. Drawing by Ib Rudoor.

er tale om en bebyggelse af landsbytype. En bestemmelse af Lisbjerg IIbopladsen er ikke sikker, men måske er den en forgænger eller efterfølger for Rugårdlandsbyen.

Gravpladserne ligger tæet omkring Rugårdlandsbyen. Der er store og små gravpladser under flad mark eller i gamle bronzealderhøje, og enkeltliggende grave under flad mark eller i ældre gravhøj. Gravlæggelserne satte ind i sen forromersk jernalder, og mange fortsatte til hen mod slutningen af 2. århundrede. Der er også gravpladser, der først blev taget i brug i 1. århundrede. Andre pladser ophørte allerede i samme århundrede. Det er altså et temmelig broget billede, der tegner sig.

Den største af gravpladserne er Bulbjerg. ${ }^{11}$ Her udgravede Carl Neergaard 97 sikre jordfæestegrave samt en del brandgrave, der dog skal dateres til den ældre del af førromersk jernalder. Der er næsten $1,5 \mathrm{~km}$ til Rugårdpladserne, og man må derfor forvente, at der har ligget en boplads eller landsby nær Bulbjerggravpladsen.

Men som ved Rugård ligger den store gravplads ikke alene. Ikke langt herfra er udgravet andre, og igen ser vi gravene anlagt i små og store gravpladser under flad mark eller i ældre gravhøj.

Den overordnede udbredelse af gravlokaliteter tyder på, at der mellem landsbyen ved Rugård og en landsby for Bulbjerg går en grænse langs den nuværende vej mellem Lisbjerg og Elev. Den løber gennem Lisbjerg Skov $i$ en markant lavning.

Bulbjerggravpladsen har som nævnt et større antal brandgrave fra en ældre del af førromersk jernalder (fig. 6), men alle jordfæstegravene stam- 

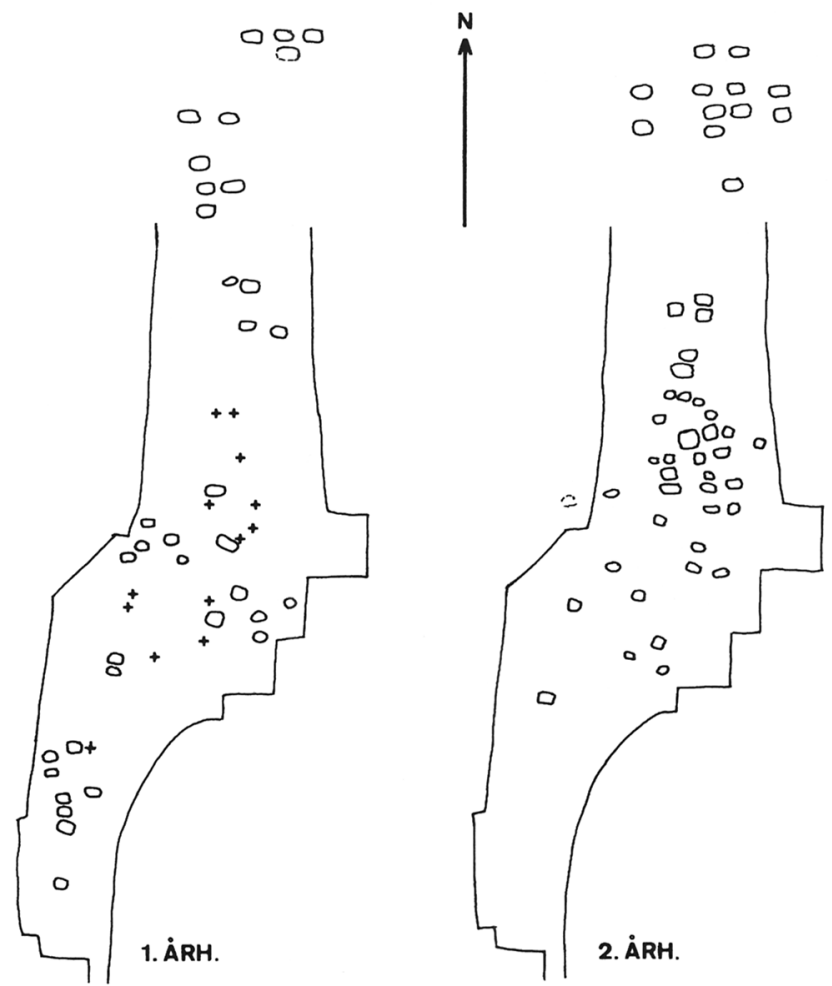

0
0
0

Fig. 6. Bulbjerggravpladsen (Mette Høj, se note 3), adskilt i grave fra 1.årh. og grave fra 2.årh. Brandgravene fra førromersk jernalder er afsat med krydser. Bearbejdet på grundlag af Mette Højs forlæg. Tegning: BHN og Ib Radoor.

The Bulbjerg burial site (Mette Høj, see note 3) with graves from the 1st and 2nd century AD. Cremation graves from the Pre-Roman Iron Age are marked with crosses. Adapted from Mette Høj's original. Drawing by Ib Radoor.

mer fra ældre romersk jernalder. På den nordlige del af gravpladsen ligger en gruppe rigere grave, heriblandt den tidligere nævnte. Hvis man betragter udbredelsen af gravene på pladsen under et, fremtræder de som én stor gravplads. Viser man derimod kun gravene fra 1. århundrede, fremgår det ret klart, at man har påbegyndt gravlæggelserne i små grupper, der oprindeligt var isoleret fra hinanden. Det er først, når gravene fra det 2. århundrede bliver lagt på planen, at indtrykket af en samlet gravplads bliver dominerende. Den sydlige gruppe er ophørt her. Det er altså kun gravlæggelserne i den centrale del og nordlige del af feltet, der blev fortsat. Den nordlige gruppe ligger fortsat for sig selv.

Det skal med, at der i en den lille mose Høgsmose, som ligger lige nordvest for Lisbjerg i $1872 \mathrm{blev}$ fundet en armring af guld fra perioden.

Efter det beskrevne at dømme eksisterede der i ældre romersk jernalder to bosættelsesområder henholdsvis nord og nordøst for Lisbjerg. 


\section{Flere Lisbjergpladser}

Nye undersøgelser i form af markvandringer, prøvegravninger og egentlige udgravninger har nu vist, at fundene også er talrige længere mod vest ved Egådalen. Man skal blot til ejendommen Vestergård lidt sydvest for Lisbjerg. Her blev for få år siden i forbindelse med Århus Kommunes planlægning af erhvervsområder lokaliseret et stort bopladsområde på nordsiden af en markant erosionsrende (fig. 7). ${ }^{12}$ Opsamlede lerkarskår daterede pladsen til sen førromersk og ældre romersk jernalder. Foreløbig kan en enkelt grav knyttes til denne landsby, men der er oplagte muligheder i området, som ikke har været undersøgt endnu.

På den anden side af erosionsrenden, nogle fă hundrede meter videre mod sydvest, lå indtil for nylig Lisbjerggaard. Lige i udkanten af gårdhaven udgravede Neergaard en rig grav fra begyndelsen af 2. århundrede. Lidt vest for gården blev fundet og prøvegravet en meget stor boplads. ${ }^{13}$ Denne ligger tæt ved den på stedet ret stejle skråning ned mod dalbunden og på samme tid meget højt i terrænet med vid udsigt mod øst til Lystrup Enge og den nordlige Århusbugt. Kort sagt lå Klokhøje I, som landsbyen kom til at hedde, et sted hvorfra man kunne overvåge og kontrollere al færdsel ind og ud af dalen.

Nord for bopladsområdet lå en række overpløjede gravhøje. I kanten af disse var anlagt grave fra ældre romersk jernalder. Det var kun et mindre antal, der blev fundet ved denne lejlighed, eftersom der kun blev foretaget mindre udgravninger i højene. Stadig nord for landsbyen, men nærmere Lisbjerggaard, lå under flad mark en gravplads med tre brandgrave, fire jordfæestegrave og en lerkarnedsættelse, Lisbjerggård I-gravpladsen. ${ }^{14}$ En amatørarkæolog udgravede i 60'erne eller 70'erne en lille gruppe på tre jordfæstegrave på samme skråning. Hvor præcist disse tre grave lå, er ikke optegnet, og de blev ikke genfundet. Ikke desto mindre må man regne med, at der i forbindelse med denne landsby blev anlagt et antal mindre gravpladser lidt uden for det bebyggede område.

På Lisbjerggaard I-gravpladsen indeholdt en af brandgravene et tveægget jernsværd af Latène-type fra sen førromersk jernalder. En af jordfæstegravene var ligeledes en våbengrav. I dette tilfælde var det blot en lansespids, der var givet med. En af jordfæstegravene vakte særlig interesse. Overalt i gravfylden blev set små grønne dækvinger fra insekter. En prøve af denne fyld blev siden undersøgt meget nøje og mange insektdele kunne frilægges. Insektresterne er blevet undersøgt af Toke Skytte fra Naturhistorisk Museum i Århus, der meddeler, at der med de grønne dækvinger var tale om en art af bladbiller, men at der også var rester af en rovbille. Dette kunne tolkes derhen, at de overordentlig mange bladbiller, der blev set i gravfylden, måtte være de mindre heldige af en større sværm, der landede på den netop opgravede jord.Vi så resterne af dem, 
Fig. 7. 1: 100000 kort med angivelse af 1.Vestergårdbopladsen, 2. Vestergård II graven, 3. Klokhøje I landsbyen, 4. Lisbjerggård I gravpladsen. Øvrige gravpladser er afsat med sort prik. Tegning: Ib Radoor.

1:100,000 map showing: The Vestergård settlement. 2.The Vestergård II grave. 3. The Klokhøje I village. 4. The Lisbjerggård I village. Other burial sites are marked by a dot. Drawing by Ib Radoor.

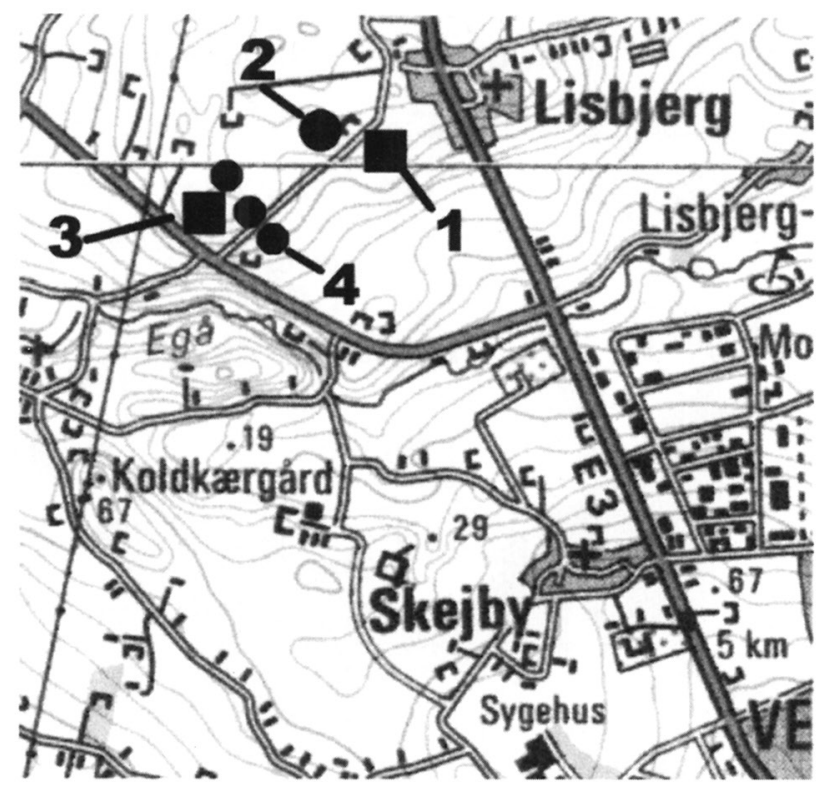

der ikke kom væk. Denne type ca. 0,5 cm store bladbiller sværmer i anden halvdel af maj til første halvdel af juni. Rovbillen er aktiv om natten og må derfor være faldet ned i graven, mens den stod åben. Insekterne angiver altså ret nøje årstiden for denne begravelse, samt at graven blev anlagt mindst en dag før selve begravelsen fandt sted.

\section{To bosættelsessystemer ved Søften}

Hinnerup Kommune besluttede samtidig med Århus Kommune at udvikle et erhvervsområde. Til formålet var opkøbt Hørkærgård og Damgårdens jorde, som ligger i den nordøstlige udkant af Søften. På arealet var i forvejen registreret adskillige gravhøje og et formodet urnegravfelt fra den tidlige førromerske jernalder. Urnegravfeltet var for længst sløjfet, og med få undtagelser var de mange gravhøje blevet pløjet stærkt ned. Nye markvandringer ledte til fund af høje, som ikke tidligere var opdaget. Det har endnu ikke været muligt at udgrave alle de overpløjede gravhøje inden for erhvervsområdet. Det vil ske i takt med, at virksomhederne viser køberinteresse. Men der er i to nyfundne gravhøje udgravet gravpladser fra sen førromersk og ældre romersk jernalder. Hertil skal lægges, at der på højderne i områdets østlige del samt længere mod øst, hvor motorvejen nu løber (fig. 8), i tidens løb er fundet og udgravet både grave under flad mark og gravhøje med grave fra ældre romersk jernalder. 


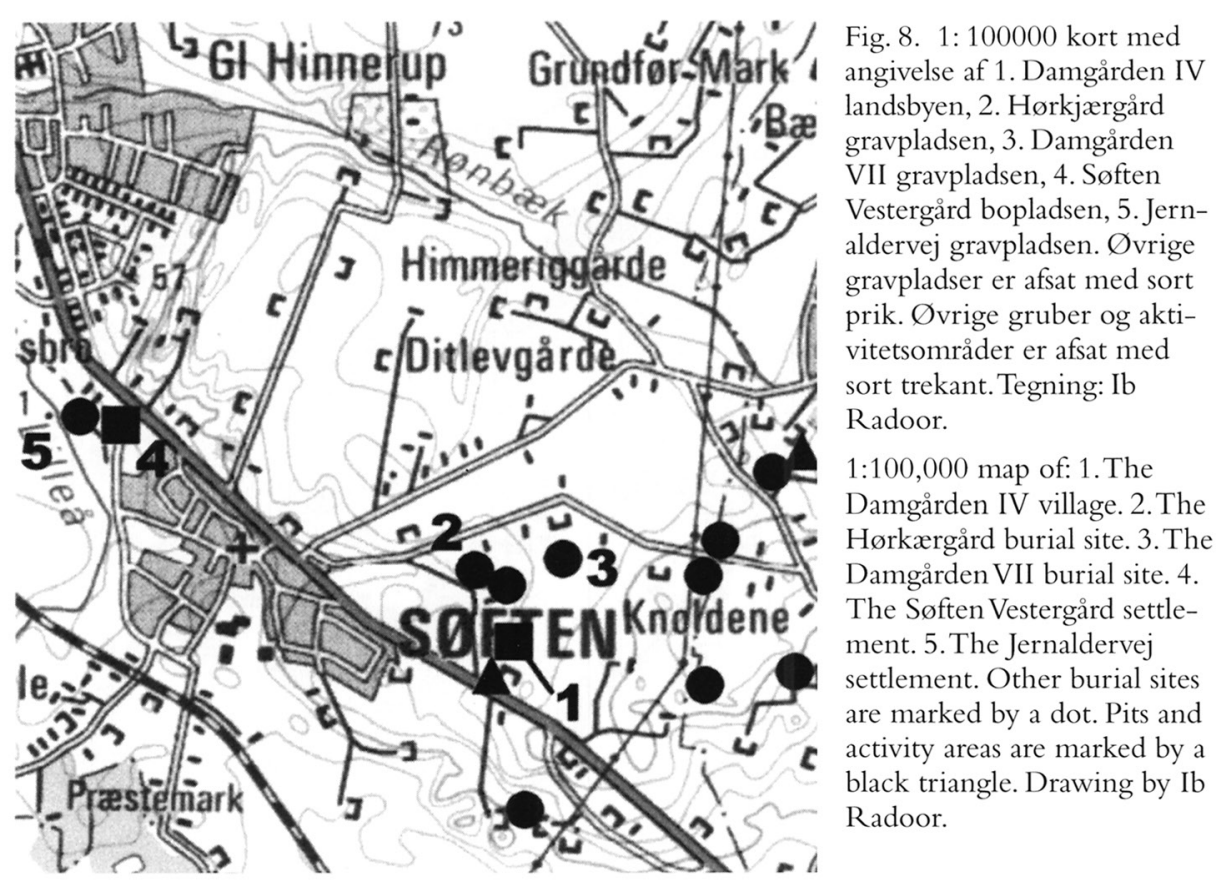

Mange af gravhøjene er oprindeligt stenalder- eller bronzealderhøje, men de blev benyttet igen i ældre jernalder. Der er blandt fundpunkterne i den østlige del af dette bosættelsessystem også fundet kraftige stensætninger og ildsteder, som dog hverken kan tolkes som boplads eller gravplads, men som dog er dateret til ældre romersk jernalder. Syd for erhvervsområdet falder terrænet ned mod engene mellem Egåen og Lilleåen. Her er indtil videre kun gjort få fund. Tæt syd for den nuværende Hørkærgård blev fundet rester af bopladsaktiviteter, der var samtidige med det urnegravfelt, som allerede er nævnt. Selve bopladsen hertil er endnu ikke fundet.

Det er derimod bopladsen fra sen førromersk og ældre romersk jernalder, der lå i et område sydøst for Hørkærgård (fig. 9). ${ }^{15}$ Dens ældste faser viser en landsby, hvor husene ligger noget spredt på bopladsområdet. Husene har højst fire sæt tagstolper og indgangsstolper $\mathrm{i}$ både nordog sydside. Til husene i denne ældre landsbyfase knyttede sig småhuse, såkaldte firstolpehuse. Hver gård har haft to faser. Gårdene i landsbyen synes pludselig at blive bygget som på en linie, og småhusene bliver ikke bygget mere. Antagelig blev småhusenes funktion i den yngre landsby integreret i selve langhuset, der næsten i alle gårde blev gjort længere. Det vil føre for vidt at redegøre detaljeret for udviklingen af de enkelte gårde, men det var en ganske betydelig omlægning, der fandt sted. I den yngre landsby kunne der være stolpehuller fra helt op til seks husfaser i en 
Fig. 9. Damgården IV landsbyen. Landsbyens 2 ældre faser og firstolpehuse er fremhævet. Tegning: BHN og Ib Radoor.

The Damgården IV village. The two first phases of the village and houses with four posts are accentuated. Drawing by BHN and $\mathrm{Ib}$ Radoor.

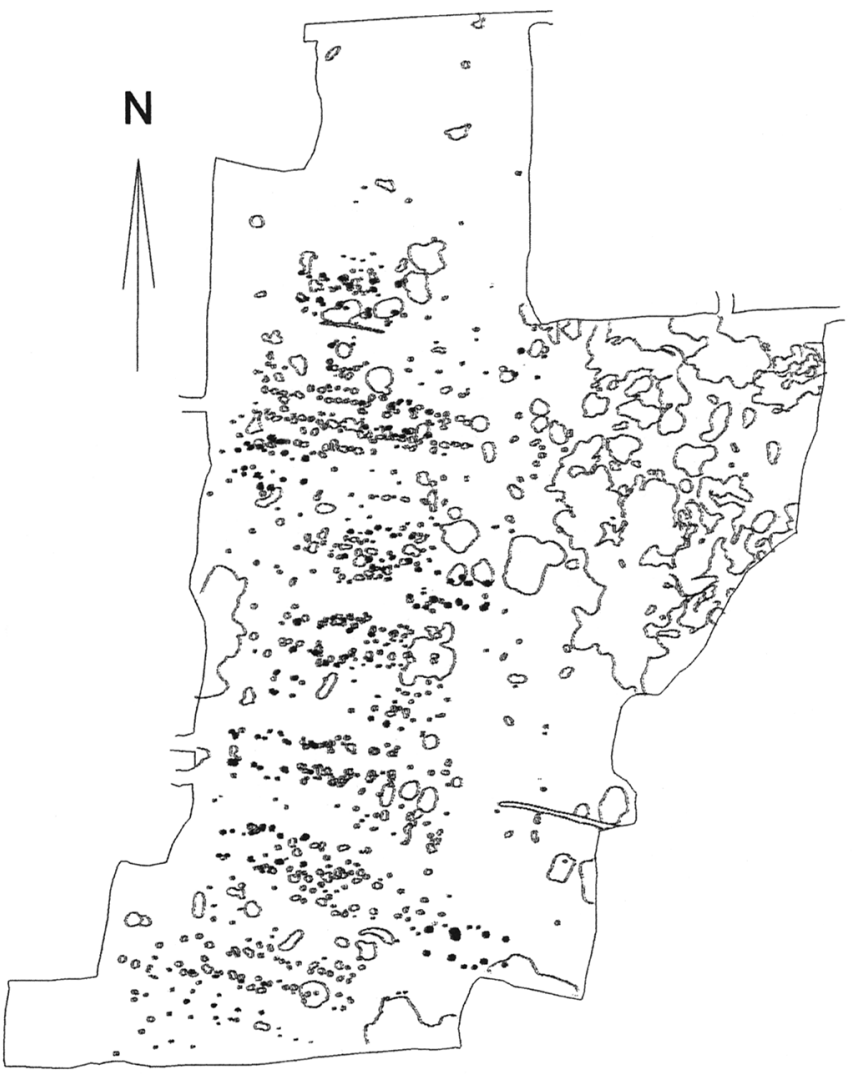

$20 \mathrm{~m}$.

gård. Nogle huse var brændt og derpå genopført. Andre må være revet ned på grund af alder og derpå genopført. Sxtter man levetiden for et hus af almindelig jernaldertype til ca. 30 år, vil der på Damgården IV være gårde alene $i$ den yngre landsby, der eksisterede i næsten 200 år. Oversigtsplanen (fig. 9) viser, at den enkelte gård kun kunne ændre placering i meget begrænset omfang og da ofte kun i øst-vestlig retning. Der ser altså ud til at have været en meget stram parcelering, ligesom det var tilfældet på Sommerlyst I ved Skejby. Landsbyens lange levetid bliver understreget af de mange og store affaldsgruber, der lå lige øst for husene. Tæt ved nogle af gårdene og formentlig hørende til landsbyens yngre faser lå en del ret små gruber af cirkulær form med stejle sider og flad eller let rundet bund. Disse gruber kan tolkes som siloer eller en slags kældre.

Den xldre landsby bestod af op til ni gårde. I den yngre blev antallet efterhånden reduceret til fem gårde. 
I nogen afstand fra landsbyen, blandt andet sydvest for den, blev fundet gruber med keramik, der daterede dem til ældre romersk jernalder. Men huse var der ikke. Gruberne må være anlagt ude på landsbyens marker. Formålet med at anlægge gruber borte fra landsbyen er ukendt, men det er et ganske almindeligt forekommende fænomen i perioden.

En af de nyfundne gravhøje lå ca. 150 meter nordøst for landsbyen. ${ }^{16}$ Den var stærkt nedpløjet, men ikke desto mindre indeholdt den ni grave. Нøjen var oprindeligt opført over en mandsgrav fra den yngste del af stenalderen, og manden var gravlagt med en flintdolk og syv fligede pilespidser. De otte grave fra ældre romersk jernalder lå spredt i gravhøjen. Ingen var rigt udstyret, men et par grave var udformet specielt. Den ene havde en bådformet stenramme, og i "båden" var nedsat en bulkiste (fig. 10). En anden grav havde en bundbrolægning udført af udelukkende flade, røde sten. En af højens brandgrave, en brandplet, havde en næsten $40 \mathrm{~cm}$ lang sammenbøjet lansespids af jern, samt en noget ødelagt skjoldbule.

En anden nyfunden og udgravet gravhøj må være anlagt i ældre romersk jernalder. Denne gravhøj lå lige nord for Hørkærgård, kun to hundrede meter fra landsbyen. ${ }^{17}$ For en del år siden er fundet urner nær højen, som tyder på, at der kan have været flere grave tæt ved. Sådanne grave blev dog ikke fundet ved prøvegravningerne. Der var ingen anlæg

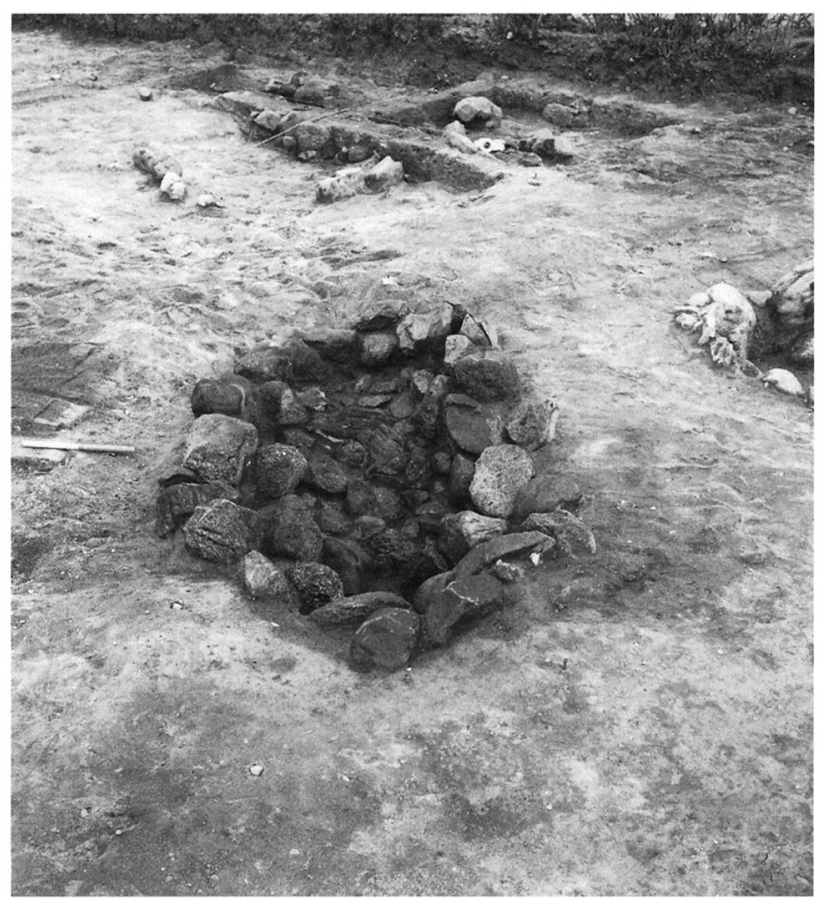

Fig. 10. Den bådformede grav på Damgården VII gravpladsen. Foto: BHN.

The boat shaped grave on the Damgården VII burial site. Photo: BHN. 
Fig. 11. Gravpladsen ved Jernaldervej under udgravning. Foto: Jens Jeppesen.

The burial site at Jernaldervej under excavation. Photo: Jens Jeppesen.

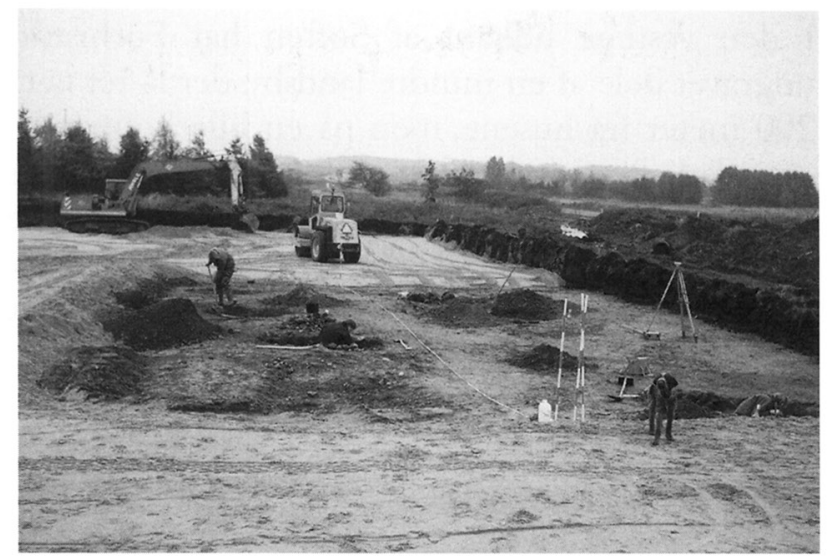

ældre end romersk jernalder i denne høj. Selvom højen var stærkt nedpløjet, var der dog endnu bevaret en 2,5-3,5 meter bred stenbræmme omkring højen. Oprindeligt har vel hele højen været dækket af sten, men at dømme efter stenbræmmens hældning mod centrum af højen, har denne aldrig haft nogen højde af betydning. Gravanlægget må snarest tolkes som en røse.

To af jordfæstegravene i røsen var meget store. Den ene udmærkede sig dog ikke ved et specielt rigt gravudstyr, men der blev fundet et bæltesspænde af jern samt flere lerkar af god kvalitet. Den anden grav var en kvindegrav, som ligeledes indeholdt en lerkaropstilling af høj kvalitet. Hvor den døde må have ligget blev i halsområdet fundet syv glasperler med indlagt sølvfolie. Ved hofteområdet blev fundet metaldele til et bælte. Det bestod af et smukt udført bæltespænde og en remendedup af bronze samt et større antal hueformede tinstifter, der havde været monteret i række på bæltet. Denne bæltetype er meget sjælden, og kvinden må have hørt til blandt de socialt bedst stillede i landsbyen. Gravene blev af keramikken dateret til 2. århundrede. De øvrige jordfæstegrave og brandgrave kunne blot dateres til ældre romersk jernalder.

I en af gravhøjene i den østlige del af området blev for mange år siden fundet en kvindegrav med to fibler af bronze og en fingerring af sølv. Som tidligere nævnt er der fundet flere grave fra perioden i det stærkt kuperede område et par hundrede meter øst for landsbyen.

Mod syd, ned mod engene, blev der på vestranden af en lille tørvemose ved Stiivelsgaard fundet to lerkar fra ældre romersk jernalder. Sammen med lerkarrene fandt man et menneskeskelet og et skelet af en hund med rester af reb om halsen. Der kan med dette fund være tale om moselig, men det kan også være en grav. 
I den vestlige udkant af Søften har Forhistorisk Museum Moesgård udgravet dele af en mindre landsby, der lå ret tæet på engen. ${ }^{18}$ Mindre end 200 meter fra husene, men på en lille holm ude i engen blev fundet en gravplads bestående af seks jordfæestegrave (fig. 11). ${ }^{19}$ I den fugtige jord var bevaret meget af kistetræet, og i én af gravene var det muligt at udtage prøver af et materiale, der kan være rester af en pude under den dødes hoved. En undersøgelse af dette materiale viste nemlig, at det blandt andet bestod af dunhammerfrø.

\section{Jernalderbosættelsen i Egådalen}

Der er nu beskrevet otte bosæettelsesområder i Egådalen, et syd for og syv nord for åen. Der var flere typer repræsenteret. Enkeltgårde som Børglum og måske Lisbjerg Terp, store landsbyer som Sommerlyst I og Damgården IV og små bebyggelser som Søften Vestergård med kun to til tre gårde, samt endelig landsbyer, som er lokaliseret, men endnu ikke udgravede. I bosættelsesområdet ved Skejby blev fænomenet flyttelandsby efter alt at dømme påvist. Muligvis er det samme tilfældet i forholdet mellem bopladserne Rugård og Lisbjerg II.Ved Søften lå landsbyen Damgården IVdog på samme sted i mindst 200 år. Sommerlyst I i Skejby var en landsby, hvor husene til enhver tid lå spredt. I Damgården IV eksisterede denne type landsby også i de første par faser, for så tilsyneladende pludseligt at blive omlagt og fastholdt i en parcelering. På Damgården IV var det muligt at påvise, at man gravede gruber og foretog andre aktiviteter også uden for landsbyen.

Kortlægningen af bosættelserne viser, at landsbyerne i forreste række på nordsiden af ådalen lå med en indbyrdes afstand på ca. en kilometer. Der er ikke inddraget bebyggelser placeret længere mod nord. Samme afstand kan vel forventes langs sydsiden af dalen. Hver landsby havde derfor et råderum på omkring en kvadratkilometer. Indenfor og måske mest $\mathrm{i}$ udkanten af dette område blev undertiden oprettet enkeltgårde. Ved Børglumvej blev der ikke fundet en gravplads, men det var tilfældet ved Lisbjerg Terp.

Ved Rugård/Lisbjerg II, Klokhøje og Hørkjærgård/Damgården/Søften Vestergård er konstateret sikre landsbyer, og ved Bulbjerg må der også have været en landsby. I fire af disse tilfælde anlagde man omkring hver landsby et antal gravpladser. Der var store og små gravpladser og der var enkeltgrave. Gravpladserne blev næsten altid placeret i nogen afstand fra bopladsen. Dette kan hænge sammen med en opdeling af jorden $i$ en indmark, som var den intensivt dyrkede jord, og en udmark, som blev benyttet til andre formål. Adskillige af gravpladserne synes, efter afstanden til 
landsbyen at dømme, at være placeret lige på grænsen mellem indmark og udmark, men der må også have været gravpladser i udmarken. Mange gange er der her tale om grave, som ligger alene.

Placeringen af gravpladserne har ikke været tilfældig. Det kan heller ikke være et tilfælde, at de oftest fik en beskeden størrelse, for det meste med færre end 10 grave pr. plads.Vi ved ikke, hvor mange personer, der boede i hver gård på et givet tidspunkt. Men antager vi, at der mindst var mand og kone, samt et antal børn, så vil der i Damgården IV landsbyens fem gårde sikkert have været mindst 25 personer. Hertil skal lægges de ældre. I løbet af 200 år ville det give en ret stor gravplads, hvis landsbyen begravede i fællesskab. Men det skete ikke. Ikke engang på Bulbjerg begyndte begravelserne på en fælles landsbygravplads, men muligvis blev den det $\operatorname{dog}$ i 2 . århundrede. De mange små gravpladser lader sig langt bedre tolke som anlagt i tilknytning til den enkelte gård i landsbyen. Dermed er det lettere at forstå det store antal gravpladser i området.

Sen førromersk og ældre romersk jernalders bosættelse i Egådalen lader sig ikke indpasse $\mathrm{i}$ et på forhånd fast defineret bebyggelsesmønster. Helt lokale forhold bestemte, hvordan en landsby eller en gård opstod og udviklede sig. Men det har været muligt at påvise et gravplads - bopladsmønster, der blev gentaget adskillige steder langs ådalen. Dette mønster er formentlig repræsentativt for hele området.

\section{NOTER}

1) Bulbjerggravpladsen er publiceret som katalog af Hans Norling-Christensen i: Eldre romersk Jarnalders Grave i Århus Amt. København 1954. Se også : Neergaard, C.: Jærnalders-Gravpladserne ved Lisbjær. Nationalmuseets Arbejdsmark 1928.

2) Som note 1 .

3) Mette Høj : Bulbjerg-gravpladsen. En analyse af keramikken på en østjysk lerkargravplads fra ældre romersk jernalder. Hikuin 10. 1984.

4) Forfatteren takker N. K. Pedersens Legat for midler, der muliggjorde, at manuskriptet kunne blive udarbejdet.

5) Ifølge Museumslovens $\$ 26$ påhvilede det Århus og Hinnerup Kommuner som offentlige bygherrer at betale for de arkæologiske undersøgelser. Forhistorisk Museum Moesgård takker begge kommuner for et godt samarbejde.

6) FHM 3791 Sommerlyst I. Udgravet af Bjarne Henning Nielsen 1992.

7) Analyserne af de forskellige lertyper blev foretaget af kemiingeniør Helge Hansen, Byggeteknisk Institut, Hasselager.

8) FHM 3792 Sommerlyst II. Udgravet af B.H.N 1992.

9) To grave med samme fundkombination kommer fra Bulbjerggravpladsen, men ellers er den fătallig med i alt 8 grave på landsplan. Se: Hedeager, L. og K. Kristiansen : Brendstrup - en fyrstegrav fra den romerske jernalder, dens sociale og historiske miljø. Kuml 1981, s.115, fig. 34.

10) FHM 3634 Børglumvej. Publiceret i : Bent Aaby, David Robinson og Anne Bloch Jørgensen: En gård fra førromersk jernalder og dens omgivende landskab. Kuml 1991-92.

11) Som note 1 og 3 . 
12) FHM 3485 AO. Ikke udgravet.

13) FHM 3485 (). Klokhøje I. Provegravet af B.H.N. 1990.

14) FHM 3485 U Lisbjerggård I og FHM 3485 R Klokhøje II. Udgravet af B.H.N. 1990).

15) FHM 3567 E Damgården IV. Udgravet af B.H.N. 199().

16) FHM 3567 K Damgarden VII. Udgravet af B.H.N. 1990)

17) FHM 3567 M Horkjærgård. Udgravet af B.H.N. og et kursushold fra Folkeuniversitetet i Århus 1994 .

18) FHM 3183a Soften Vestergård. Udgravet af Anne Marie Mortensen 1986.

19) FHM 3353 Jernaldervej. Udgravet af Jens Jeppesen 1988.

\section{Iron Age finds from the valley of Egå}

For a long time it has been known that the Lisbjerg area North of Århus has many graves from the Late Pre-Roman and Early Roman Iron Age - in other words: the time from c. 5()BC until c. 2()() Al). Inhumation graves from the Early Roman Iron Age are particularly conspicuous, both because of their form and their content. Because of the quite large number of clay vessels which are usually found in each grave, this grave type became known at an early date as "East Jutland Pottery Graves".

About the beginning of the 20th century the National Museum keeper Carl Neergaard undertook excavations on several hundred graves in this area. The best known site was the Bulbjerg burial ground. At that time it was more difficult to find the settlements to which the burial grounds belonged. However, some were found but they were only investigated to a very limited degree. The reason for this was that economically justifiable methods for the uncovering of vast settlement areas from Prehistoric periods were not developed until the 1960s.

Since the 197()s Forhistorisk Museum Moesgard has participated in the hunt for Iron Age settlements and, since the beginning of the 199()s, the location and excavation of these settlements has speeded up.

There are several reasons for this intense archaeological activity. In particular, the municipalities of Århus and Hinnerup wanted to prepare large areas for sale for industrial development along the valley of Egå, by which Lisbjerg is situated.

The Ega valley is a wide sub-glacial stream trench in the characteristically undulating landscape of Eastern Jutland. The sides of the valley are quite steep in some places but at others they fall evenly towards the bottom of the valley from both North and South. The water of the Egå runs through the valley into the meadows at Lystrup and from there flows into the Bay of Århus.

The soil on the hillsides and on the hills above the valley is amongst the best in Jutland. The valley itself offered meadows, fresh water and fields for animals and crops.

In this article an attempt is made to prove a relationship between the burial grounds and the settlements that are now known from the Early Iron Age. The settlements are either completely excavated, or established through trial excavations, located through reconnaissance of the topsoil. The burial grounds have all been completely or partly excavated. All the sites mentioned are West of Lystrup Enge ('enge' means 'meadows') and the upper part of the Egà valley.

South of the Egå, near Skejby Hospital, there is a settlement system consisting of two villages, one succeeding the other. Only one of them has been excavated, the Sommerlyst I site, whereas trial trenches were made at the other site. Sommerlyst I consisted of 16 longhouses. They were not all contemporary but it was possible to observe how the individual 
house had been rebuilt, added to, made smaller and removed. It seems as if the individual houses were kept with in a strict "lot" system. The village had a burial ground with 17 graves attached to it. Two of the graves were different from the rest in terms of size and grave goods. 1)etails relating to the form of the graves and their contents illustrate the wide variations in the grave appearance of this period. The discovery of more grave sites is to be expected in spite of the density of the modern settlement (fig. 1-4).

A village was not the only settlement type found from the period in question. At Borglumvej a solitary farm consisting of a long-house and a smaller building was excavated. The most important contribution made by this site is that a macro fossil investigation was carried out, as well as pollen analyses from layers in a small boggy area immediately next to the farm. The analyses showed that the landscape was open and tree-less, that different types of grain were grown, and that a variation of other plants and seeds were gathered. The boggy area, which was a pond at the time of the farm, was presumably kept clean (fig. 1).

The previously known burial grounds just to the North of Lisbjerg, by the farm of Rugard, as well as the burial grounds at and near the Bulbjergbanke to the East of Lisbjerg were probably related to two settlements. At the farm of Rugard two settlements (or rather, two phases of a moving village) have been located and it is possible to see how the grave sites were located around the village. A similar pattern must apply to Bulbjerg but here the village has not yet been found - or perhaps it disappeared during extraction of gravel. It has been demonstrated that even the very large Bulbjerg burial ground originally consisted of several smaller grave sites (fig. 5-6).

Further into the valley west of Lisbjerg a corresponding burial ground/village system has been established at the farms of Vestergård and Lisbjerggård (Klokhøje) (fig. 7). Similar associations were found in an area east of the small town of Soften as well as in an area west of Soften (fig. 8). In the eastern system the village called I)amgarden IV was excavated along with traces of various activities from a larger area, which must have originated from the Damgarden IV village (fig. 9). In the same area a couple of smaller burial grounds in burial mounds and in stone burial cairns have been excavated, and it should be noted that several graves had previously been excavated in this area, (figs. 1()-11). The system west of Soften consisted of a small village and - about 20() metres from this - a small burial ground with six inhumation graves (fig. 12).

So far eight settlement sites in the Ega valley have been described, one south and seven north of the river. Several types are represented. Solitary farms, as at Borglum and perhaps Lisbjerg Terp, large villages, such as Sommerlyst I and Damgården IV, small settlements, as at Soften Vestergård with only two or three farms and, finally, villages which have been located but not yet excavated. The settlement area of Skejby probably represents a moving village. The same may be the case of the Rugard and Lisbjerg II settlements. However, at Soften, the Damgarden IV village stayed at the same spot for at least 2(0)() years. In the Sommerlyst I village at Skejby the houses were at all times scattered. At Damgarden IV this type of settlement existed during the first couple of phases but then the village was suddenly re-arranged and, after this, the houses stayed within a strict "lot" system (fig. 9). In this village it was also possible to establish pit digging and other activities outside the village.

The mapping of the settlements shows that at first the villages along the Northern side of the valley were situated with an interval of c. $1 \mathrm{~km}$. However, it should be borne in mind that no settlement further to the north has been included in the investigation. The same distance can be expected on the southern side of the valley. Each village thus had a liberty of action of c. 1 square kilometre. Within - or rather at the outskirts of this area - solitary farms were sometimes established. A burial site was found at Lisbjerg Terp, but none at Borglumvej.

At Rugård/Lisbjerg II, Klokhøje and Hørkærgård/1)amgården/Søften Vestergård, villages have been positively established, whilst a village must have been situated at Bulbjerg. In four of these cases a number of burial grounds were established around each village - some large, some small and some 
just consisting of a single grave. The burials were almost always placed at some distance from the settlement. This may be explained by a division of the land into intensively cultivated home fields and a common which was used for other purposes. To judge from the distance from the village, several of the burial grounds were placed on the border between the home fields and the common, but burials must also have been placed in the common. These are often single graves.

The location of the burial grounds was not chosen at random. It is no coincidence either that they were often of limited size, mostly consisting of less than 10 graves per site. We do not know how many people lived at each farm at any given time. But if we assume that at least a man and his wife and a number of children lived on each farm, the five farms of the Damgard IV village, for instance, probably housed at least 25 people. Add to this the previous generations and during a period of 200 years this would give quite a large burial ground, if the village buried their dead together. However, this was not the case. Not even at Bulbjerg were the first burials made at a common village burial ground. However, this might have been the case by the 2 nd century AI). The many small burial grounds should rather be interpreted as being associated with each individual farm in the village. Such an interpretation helps to explain why the area contains so many grave sites.

The Late Pre-Roman and Early Roman Iron Age settlements in the Egå valley do not fit into any pre-defined settlement pattern. Local conditions decided how a village or farm came into existence and how it developed. But it has been possible to demonstrate a settlement-burial ground pattern, which was repeated at several places along the valley. This pattern is probably representative of the whole area.

Bjarne Henning Nielsen Moesgård Museum

Translated by Annette Lerche Trolle 